Отримано: 25 серпня 2021 року

Прорецензовано: 6 вересня 2021 року

Прийнято до друку: 20 вересня 2021 року

e-mail: levchenkoanna79@gmail.com

olhamoiseienko88@gmail.com

DOI: 10.25264/2519-2558-2021-11(79)-12-15
Підгорна А. Б., Моісеєнко О. А. Специфіка передачі соціального статусу персонажів художнього твору при перекладі (на матеріалі роману Дж. Фаулза «The Collector»). Наукові записки Національного університету «Острозька академія»: серія «Філологія». Острог : Вид-во НаУОА, 2021. Вип. 11(79). С. 12-15.

\author{
Підгорна Анна Борисівна, \\ кандидат філологічних наук, доцент, \\ Національний університет «Запорізька політехніка» \\ Моісеєнко Ольга Андріївна, \\ студент-магістр, \\ Національний університет «Запорізька політехніка»

\section{СПЕЦИФІКА ПЕРЕДАЧІ СОЦІАЛЬНОГО СТАТУСУ ПЕРСОНАЖІВ ХУДОЖНЬОГО ТВОРУ ПРИ ПЕРЕКЛАДІ (НА МАТЕРІАЛІ РОМАНУ ДЖ. ФАУЛЗА «ТНЕ СОLLECTOR»)}

\begin{abstract}
Стаття присвячена дослідженню сочіолінгвістичних аспектів вивчення сочіального статусу та його вираження в художніх творах через мовлення персонажів. Особлива увага приділяється опису ключового поняття «соціальний статус» як складового елемента образу літературного персонажа та розгляду особливостей мовної характеристики персонажа в иілому. У статті представлено результати аналізу мови головної героїні роману Дж. Фаулза «Тһе Соllестог», яка вирізняється особливою поетичністю та емочійністю. В якості мовних засобів виокремлюються не лише лексичні, а і граматичні ознаки. Розглянуто та проаналізовано варіанти передачі цих стилістичних особливостей у перекладі роману украйнською мовою.

Ключові слова: соціолінгвістика, художній переклад, мовна характеристика, соціальний статус, соиіальне мовлення, стилістика, перекладацькі трансформації.
\end{abstract}

\author{
Anna Pidhorna, \\ PhD, Associate Professor, \\ Zaporizhzhia Politechnic National University \\ Olha Moiseienko, \\ Master's Student, \\ Zaporizhzhia Politechnic National University
}

\title{
THE PECULIARITIES OF CONVEYING THE SOCIAL STATUS OF FICTION CHARACTERS IN TRANSLATION (BASED ON J. FOWLES' NOVEL «THE COLLECTOR»)
}

The article is devoted to the sociolinguistic aspects of studying the social status and its reflection in literary texts through the speech of fiction characters. Particular attention is paid to the description of the key concept «social status» as a constituent element of the literary character's image as well as to the research of the ways the character and his/her linguistic peculiarities are represented in the literary text. It was hypothesized that the character's social status, education level, and worldview in general must be explicitly seen through the speech the author ascribes to the character. The article deals with the novel «The Collector» by J. Fowles and focuses on analyzing the speech peculiarities of its main character, Miranda. Her language is full of various stylistic devices and expressive means, which also testifies how open-minded this personality is, proves her ability to listen and accept different points of view. Miranda's speech can be described as extremely poetic and emotional. Concerning key linguistic features of her speech, both lexical and grammatical ones can play a role in defining the character's social status. The article also studies and analyzes the ways of reproducing the stylistic features in the Ukrainian translation of the novel made by G. Yanovska.

Key words: sociolinguistics, literary translation, speech characteristics, socialstatus, socialspeech, stylistics, translation transformations.

В останні роки предметом досліджень як вітчизняних, так і зарубіжних лінгвістів часто стає явище мовної особистості. Інтерес до цього поняття пов'язаний зі зміною системно-структурної парадигми мови на антропоцентричну, що відбулася в кінці XX століття. Лінгвістам стає цікавою конкретна людина зі своїм внутрішнім світом, ставленням до себе та до оточуючих. Серед вчених, що досліджували цю проблематику, можна назвати В. А. Звегинцева [5], В. І. Карасика [6], М. М. Кожину [8], В. О. Авроріна [1], Р. О. Якобсона [15] та інших. Мова розглядалась лінгвістами не тільки як система знаків та лексико-семантичних формувань, а і як особливий тип людської діяльності, що слугує ідентифікатором соціальних ролей. Засвоєння особливостей мови, використовуваних в конкретній соціальній групі, і правил їх застосування відповідно до виконання тих чи інших соціальних ролей є частиною процесу входження особистості у суспільство, так званий процес мовної соціалізації [1, с. 210].

Художні твори є релевантним матеріалом для вивчення соціально обумовленої поведінки, адже через різноманітні мовностилістичні ресурси, що використовують автори, можна побачити, яким чином соціальні ролі та статуси відбиваються через мовлення людини. Частково питання зв'язку мовлення персонажів творів та соціальних ролей, що надаються ним авторами, розглядаються у деяких наукових доробках [2; 7], однак, повного висвітлення це питання немає, що і обумовлює актуальність цієї статті.

Стаття присвячена аналізу основних лінгвістичних відмінностей між мовленням персонажів, що належать до різних соціальних верств, а також причин цього явища; дослідженню використання різних видів стилістичних засобів, використаних 
автором для передачі специфіки мовлення персонажів; обгрунтування використання лексичних, граматичних та синтаксичних трансформацій при художньому перекладі.

Наукову новизну статті становить новий погляд на лінгвостилістичні характеристики мовлення персонажів роману Дж. Фаулза «The Collector» [17] як на маркери їх приналежності до певних соціальних груп. Певну наукову цінність мають і спроби аналізу способів передачі цих соціолінгвістичних маркерів при перекладі роману українською мовою [12].

Методологічне значення дослідження полягає, перш за все, в можливості використання його результатів у подальших дослідженнях питання відбиття соціальних статусів та ролей через мовні засоби, як на матеріалі художніх творів, так і на матеріалі текстів інших стилів та видів.

У процесі мовної комунікації люди користуються засобами мови - іï словником і граматикою - для побудови висловлювань, які були б зрозумілі адресату. Однак, знання тільки словника і граматики недостатньо для того, щоб спілкування цією мовою було успішним: треба знати ще умови вживання тих чи інших мовних одиниць та їх сполук. Тобто крім власне граматики, носій мови повинен засвоїти «ситуативну граматику» [11, с. 5], яка наказує використовувати мову не тільки у відповідності зі змістом лексичних одиниць і правилами їх поєднання у реченні, а й в залежності від характеру відносин між мовцем і адресатом, від мети спілкування і від інших факторів, знання яких в сукупності з власне мовними знаннями становить комунікативну компетенцію носія мови.

Соціальні статуси визначають взаємовідносини індивіда з іншими членами суспільства, його відносно постійне або тимчасове положення в соціальних ієрархіях різного типу [9, с. 78]. Будь-який статус включає в себе права, обов'язки i відповідну йому нормативну поведінку. Наприклад, статус студента включає в себе відвідування занять, складання іспитів, проходження практики та ін., статус викладача - компетенцію у відповідній дисципліні, певні педагогічні навички, дослідницьку діяльність, відвідування засідань кафедри і т. п. Від людини, що володіє тим чи іншим соціальним статусом, навколишні очікують певної поведінки, що відповідає цьому статусу.

Рольові очікування не залежать від конкретної людини, а формуються разом з тим типом соціальної системи, в межах якої ця роль існує; однак, це вірно лише при абстрактному розгляді статусів і пов'язаних з ними ролей. Реальний індивід, отримавши певний статус, починає освоювати відповідні ролі; соціологи називають цей процес інтерналізацією ролі [5, с. 55]. Незважаючи на те, що сукупність очікувань, притаманна тій чи іншій ролі, складається з набору констант, що диктують індивіду певну поведінку, інтерналізація ролей кожною людиною відбувається через призму ії особистого досвіду i під впливом того мікро- і макросередовища, до якого він належить. Тому і виконання ролей як обумовлених постійними $\mathrm{i}$ довгостроковими соціальними характеристиками індивіда, в тій або іншій стандартній ситуації варіює від особистості до особистості, від однієї соціальної групи до іншої. Важливо, однак, що ця варіативність знаходиться в певних межах - поки вона не суперечить очікуванням, властивим ролі, і не порушує соціальних норм [14, с. 93].

Такі соціальні категорії, як «статус» та «соціальна роль», деякі дослідники розглядають як фактори, що впливають на стилістичне варіювання мови. Увага до постаті того, хто говорить, як до одного з основних факторів, що обумовлюють мовленнєві відмінності, виділення різних типів мовців залежно від соціальних і ситуативних ознак характерно для низки сучасних досліджень в області стилістики [19, с. 66].

Соціальний статус вказує на соціальне становище людини в суспільстві, яке засноване на відмінностях влади, престижу і соціального класу, а також на пов'язані з ним права та обов'язки. Найширші категорії соціальних класів - це верхні, середні і нижчі класи, які корелюють 3 мовними варіантами (стандартна літературна англійська або їі нестандартні варіанти). Основні категорії влади включають в себе більш високі, рівні і більш низькі позиції, які співвідносяться з рівнями формальності (або «стилями мови»: більш формальними, нейтральними, більш розмовними) [4, с. 154].

Б. Бернштейн розробив метод класифікації мовних кодів згідно з різними акцентами на вербальному і невербальному спілкуванні [16, с. 55-67]. Він стверджував, що такі фактори, як орієнтація на сім'ю, соціальний контроль, мовний зворотний зв'язок і соціальний клас, сприяли розробці двох кодів: складного і обмеженого. На основі аналізу мови двох груп підлітків, що належать до різних верств суспільства (але з рівним інтелектуальним рівнем розвитку), дослідник проілюстрував свою гіпотезу про те, що мова нижчих шарів суспільства є лексично біднішою і синтаксично простішою за мову середнього класу.

Соціолінгвіст Дж. Гумперз, який також досліджував соціальні коди, погоджується з Б. Бернштейном та наводить такі приклади особливостей мови в залежності від низького та високого соціального статусу відповідно [18, с. 153]:

It looks like it ain't gonna rain today. - It looks as if it isn't going to rain today.

You give it to me yesterday. - You gave it to me yesterday.

Y'gotta do it the right way. - You have to do it the right way.

Художній стиль в цілому відрізняється від інших функціональних стилів тим, що якщо інші характеризуються загальним стильовим забарвленням, то в художньому може бути присутня різноманітна гамма стильових барв використовуваних мовних засобів [3, с. 85]. Однак, це не є «змішуванням стилів», оскільки кожне слово в художньому творі мотивовано змістовно і стилістично, всі разом вони об’єднуються однією спільною, властивою їм естетичною функцією [8, с. 198]. Відмінність художнього мовлення також у тому, що в ньому застосовуються не тільки літературні, але і позалітературні засоби мови - просторіччя, жаргон, діалекти і т. д. Однак, і ці засоби використовуються не в їх первинній функції, а в естетичній. Всі мовностилістичні ресурси присутні у арсеналі художнього мовлення. Таким чином, з лінгвістичної точки зору художній стиль характеризується використанням всіх стилістичних ресурсів наявних у мові.

Художній текст являє собою багатопланове явище, що володіє властивостями конфліктності сюжету, виразності рольової поведінки персонажів, обумовленої соціальними параметрами ситуації, тобто соціальними ролями і стереотипами, статусом персонажів, соціальним інститутом [10, с. 10]. Мова персонажа літературного твору завжди соціально обумовлена, оскільки соціальне становище, вік, освіта, професія і інші чинники не можуть не позначитися на його мовному портреті. При цьому не тільки слова, словосполучення, синтаксичні конструкції, а й акцент, вимова, сама манера мовлення вказують на соціальну приналежність мовця. Персонаж вільний «грати» на різних соціальних діалектах в залежності від задуму автора літературного твору. Тому мова того чи іншого персонажа неодмінно повинна перш за все оцінюватися з точки зору соціолінгвістичної обумовленості даної мовної характеристики [13, с. 17]. 
Роман Дж. Фаулза «The Collector», що є матеріалом цього дослідження, є відмінним зразком передачі через мовлення персонажів їх соціальної приналежності. Автор ретельно добирає слова, вирази, синтаксичні конструкції, що відбивають як мову соціального середовища, до якого належить персонаж, так і його індивідуальний характер. При цьому соціолінгвістична характеристика персонажа не обмежується його прямою мовою, переданою у вигляді самостійного речення і відповідно оформленого розділовими знаками; поряд з прямою мовою в романі представлена непряма мова, де мова одного персонажа передається іншим персонажем, а також невласне пряма мова, в якій засоби переходу висловлювання в непряму мову використовуються не в повному обсязі, а беруться тільки деякі його формальні ознаки, а при зображенні внутрішніх переживань персонажа, його думок та вражень від того, що відбувається, використовується внутрішній монолог.

Аналіз, результати якого представлено в цій статті, передбачає вивчення соціолінгвальних характеристик мовлення персонажів не тільки в аутентичному тексті роману англійською мовою, а також і в його перекладі українською, виконаному Г. Яновською [12], з метою встановлення способів перекладу, що уможливлюють адекватність передачі вищезгаданих характеристик у процесі перекладу. В цій роботі демонструють найбільш яскраві приклади специфіки мовлення однієї 3 головних героїв твору - Міранди. ÏÏ соціальний статус та освіченість є досить високого рівня, що не могло не відобразитись у їі мовленні.

Так, мова Міранди різноманітна, як з граматичної, так і з лексичної точки зору. Використовуються і складні, i прості речення, вибір лексики переважно нейтральний і розмовний. У той же час не можна не відзначити емоційність героїні, що обумовлює велику кількість емоційно забарвлених слів, виразів і спонукальних пропозицій. Саме тому особливу роль в висловлюваннях героїні відводиться епітетам, варіативність яких безсумнівно акцентує ії освіченість, розум, багатий словниковий запас. Спостерігаються слова $з$ яскраво вираженими емоційно-оціночними конотаціями - як позитивними (delicious [15, с. 83] - розкішний [10, с. 135], lovely [15, с. 83] - чудовий [10, с. 135], significant [15, с. 134] - видатний [10, c. 141], incredible [15, с. 162]-неймовірний [10, с. 177], tremendous [15, c. 149]- надзвичайний [10, с. 155], так і негативними (ghastliest [15, с. 131] - найстрашніший [10, с. 135], awful [15, с. 144] - потворний [10, с. 152], ridiculous [15, с. 99] - безглуздий [10, с. 105], miserable [15, с. 89] - жалюгідний [10, с. 95], horrid [15, с. 158] - жахливий [10, с. 163], absurd [15, с. 198] абсурдний [10, с. 204], hateful [15, с. 126] - мерзенний [10, с. 128]), що показує здатність героїні точно виражати свої емоції та почуття, а також свідчить про іiі багатий вокабуляр. Переклад цих емоційно-оціночних одиниць досить точний і також вирізняється варіативністю, що уможливлює адекватну передачу соціального статусу та освіченості героїні.

Передача комплексності та емоційності мовлення головної героїні досягаються також за допомогою синтаксичних засобів виразності. Часто можна спостерігати одночленні речення, характерні для книжкового стилю, які додають образності висловлюванням. Компресія в їі мовленні - і в оригіналі, і в перекладі - передається через такі форми замовчування, як апозіопезіс та еліпс: If only they knew. If only they knew. Share the outrage. So now I'm trying to tell it to this pad he bought me this morning. His kindness [15, с. 123]. - Коли б вони тільки знали. Якби вони тільки знали. Поділитись обуренням. Тепер я намагаюся переповісти його оцьому блокнотові, який він приніс мені сьогодні враниі [10, с. 126].

Особливістю лексичного наповнення мовлення героїні є досить велика кількість неологізмів, побудованими на основі різних способів словотворення: She was so sex-kittenish [15, с. 176]. - Вона грала роль такої собі сексуальної штучки [10, c. 178]. В оригіналі Міранда використовує словоскладання, яке у перекладі для більшої зрозумілості перетворюється на описове словосполучення. Переклад є досить вдалим і зберігає тон висловлювання.

Схожим прикладом є таке речення: I hissed a damn-you at Piers... [15, c. 178]. - Я прошипіла «Щоб тебе...» - Пірсові внизу... [10, с. 182]. Як і у попередньому прикладі, в оригіналі Міранда користується словоскладанням, але перекладач змінює його, передаючи змістовну наповненість думок героїні та ії емоції через пряму мову.

Іншим засобом створення неологізмів, яким користується головна героїня є деривація: Which is Calibanese for no [15, c. 209]. - По-калібанівськи це означає «ні» [10, с. 211]. Як бачимо, у перекладі Г. Яновська також вводить неологізм, вдало використавши типовий для української спосіб утворення назв мов.

Крім того, у своєму лексиконі головна героїня роману для утворення неологізмів активно використовує конверсію:

I mean don't knock me unconscious or chloroform me again or anything. [15, c. 44]. - Тобто не оглушуючи мене, присипляючи хлороформом [15, с. 24].

I psycho-analysed him this evening [15, p. 201] - Провела йому сьогодні психоаналіз [10, с. 204].

В обох з наведених прикладів конверсії в англійському варіанті висловлювань перекладач вимушений використовувати додавання дієслова, адже для української мови подібні перетворення іменників у дієслова є нетиповими.

Таким чином, навіть 3 декількох прикладів мовлення Міранди стає очевидним, що автор намагався вкласти в мову цієї героїні характеристики, що є властивими людині досить високого соціального статусу, освіти та виховання. Її мовлення лексично й синтаксично варіативне, достатньо експресивне і наповнене специфічними зворотами й неологізмами, здатність до утворення яких ще більше підтверджує ії̈ вільне володіння усіма засобами, що є у розпорядженні мови.

Отже, аналіз мовленнєвих характеристик персонажа художнього твору є важливим етапом при ідентифікації соціального статусу героя, зокрема його віку, рівня освіти, етнічної приналежності, певних рис характеру тощо. Тобто текст художнього твору слід сприймати не лише на семантичному, але і на поетичному рівні. Саме цим ускладнюється робота перекладача, адже розуміння змісту слів і словосполучень в художньому творі не обмежується їх буквальним значенням. Перекладач повинен розпізнати та правильно оцінити всі додаткові смисли, що вкладаються автором, і якомога точніше передати ці конотації за допомогою еквівалентних виразів або трансформацій.

\section{Література:}

1. Аврорин В. А. Проблемы изучения функциональной стороны языка (к вопросу о предмете социолингвистики). Ленинград : Наука, 1975. $274 \mathrm{c}$.

2. Бачманова О. А. Особенности речевого поведения персонажей романа «Завтрак у Тиффани» как средства художественной выразительности в контексте лингвостилистики. Молодой ученый. 2018. № 19. С. 397-399.

3. Виноградов В. В. Проблема авторства и теория стилей. Москва : Государственное издательство художественной литературы, 1961. $616 \mathrm{c}$. 
4. Дешериев Ю. Д. Социальная лингвистика. К основам общей теории. Москва : Наука, 1977. 382 с.

5. Звегинцев В. А. Социальное и лингвистическое в социолингвистике. Известия АН СССР. Серия литературы и языка. 1982. № 3. С. 51-73.

6. Карасик В. И. Язык социального статуса. Москва : ИТДГЛ «Гнозис», 2002. 333 с.

7. Князева Н. А. Средства индикации социального статуса литературного персонажа: аксиологический аспект (на материале пьесы Б. Шоу «Пигмалион»). Актуальные вопросы филологических наук : материаль III Междунар. науч. конф. Казань : Бук, 2015. C. $16-20$.

8. Кожина М. Н. Стилистика русского языка. Москва : Просвещение, 1983. 223 с.

9. Мечковская Н. Б. Социальная лингвистика. Москва : Аспект Пресс, 1996. 207 с.

10. Ржевская А. А. Языковые средства построения перспективы в дискурсе конфликта (на материале английской драмы) : автореф. дис. ... канд. филол. наук [спец.] 10.02.04 «Германские языки» / Московский гос. лингв. ун-т. М., 2014.27 с.

11. Трушникова Т. Г. Новейшие грамматики английского языка. Обучение и воспитание: методики и практика. СанктПетербург, 2014. С. 5-12.

12. Фаулз Дж. Колекціонер / пер. $з$ англ. Г. Яновської. Харків : Клуб Сімейного Дозвілля, 2017. 302 с.

13. Чижевская М. И. Язык, речь и речевая характеристика (вопросы изучения речи персонажа). Москва : Моск. гос. ун-т им. М. В. Ломоносова, 1986. 71 с.

14. Швейцер А. Д., Никольский Л. Б. Введение в социолингвистику. Москва : Высшая школа, 1978. 216 с.

15. Якобсон Р. О. Речевая коммуникация; Язык в отношении к другим системам коммуникации. Избранные работыл. Москва : Прогресс, 1985. С. 306-330.

16. Bernstein B. Some Sociological Determinants of Perception: An Enquiry into Sub-Cultural Differences. British Journal of Sociology. 1958. № 9. P. 159-174.

17. Fowles J. The Collector. Boston : Little, Brown and Company, 1963. 328 p.

18. Gumperz J. Linguistic and Social Interaction in Two Communities. American Anthropologist. 1964. № 66. P. $137-153$.

19. Labov W. The Social Stratification of English in New York City. Cambridge : Cambridge University Press, 1966.66 p. 